\title{
Predictive value of Selvester QRS score for severity of coronary artery disease in ST-segment elevation myocardial infarction
}

\author{
Caner Türkoğlua, Ömer Gençc, Taner Şekerc, İbrahin Halil Kurtc
}

a Department of Cardiology, Malatya Training and Research Hospital, Malatya, Turkey

${ }^{b}$ Department of Cardiology, Ağrı Training and Research Hospital, Ağrı, Turkey

' Department of Cardiology, Adana City Training and Research Hospital, Adana, Turkey

ARTICLE INFO

Article history:

Submitted: 13. 6. 2021

Accepted: 26. 7. 2021

Available online: 29. 11. 2021

Kličová slova:

Infarkt myokardu s elevacemi

úseku ST

Hypertenze

Selvesterovo skóre QRS

Skóre SYNTAX II

TIMI frame count
SOUHRN

Kontext: Je známo, že skóre QRS je spolehlivým prediktorem rozsahu infarktu a nepříznivé prognózy pacientů po infarktu myokardu s elevacemi úseku ST (ST-segment elevation myocardial infarction, STEMI).

Cíl: Naším cílem bylo definovat vztah mezi skórovacími systémy skóre SYNTAX II (SS-II) a skóre QRS u pacientů po STEMI.

Metody: Do studie bylo zařazeno 302 po sobě následujících pacientů $(71,8 \%$ mužů, průměrný věk $55,1 \pm 12,2$ roku) po STEMI, léčených primární perkutánní koronární intervencí (percutenous coronary intervention, $\mathrm{PCl}$ ). Pacienti byli rozděleni do dvou skupin podle hodnot SS-II (jedinci s SS-II $\leq 32$ tvořli skupinu s "nízkým" skóre [n = 241], zatímco jedinci s SS-II > 32 představovali skupinu se "středně vysokým až vysokým" skóre [n = 61]). Výsledky: Pacienti se "středně vysokým až vysokým" skóre byli starší. Hodnoty N-terminálního fragmentu natriuretického propeptidu typu B (NT-pro brain natriuretic peptide, NT-proBNP), troponinu, indexu skóre kinetiky srdeční stěny a perfuze myokardu měřená metodou TIMI frame count byly statisticky významně vyšší ve skupině se "středně vysokým až vysokým" SS-II než ve druhé skupině $(p<0,05$ pro všechny hodnoty). U pacientů ve skupině se "středně vysokým až vysokým" SS-II byla zjištěna nízká ejekční frakce ( $p<$ $0,001)$. Hodnoty souhrnného sledovaného parametru byly statisticky významně vyšší ve skupině se "středně vysokým až vysokým" SS-II $(p=0,01)$. Selvesterovo skóre QRS bylo statisticky významně vy̌̌ší ve skupině se "středně vysokým až vysokým" SS-II než ve skupině $s$ "nízkým" SS-II $(p<0,001)$. Bylo prokázáno, že skóre QRS, hypertenze, kuřáctví a hodnoty TIMI frame count představují nezávislé prediktory SS-II. Mezní hodnota skóre QRS predikující hodnotu SS-II na základě analýzy křivky ROC byla 9,0 při senzitivitě $50,9 \%$ a specificitě $84,1 \%$ (AUC 0,726; $95 \%$ Cl 0,648-0,804; $p<0,001$ ).

Závěr: Skóre QRS je spojeno se skóre SS-II predikujícím závažnost ischemické choroby srdeční a mortalitu pacientů se STEMI, u nichž byla provedena primární $\mathrm{PCI}$.

(c) 2021, ČKS.

\section{ABSTRACT}

Background: QRS score was demonstrated to be a strong predictor of infarct size and poor outcomes in patients with acute ST-segment elevation myocardial infarction (STEMI).

Aim: We aimed to determine the association between the SYNTAX score II (SS-II) and QRS score in patients with STEMI.

Methods: The study included 302 consecutive patients (71.8 \% males, mean age $55.1 \pm 12.2$ years) with STEMI who were treated with primary percutenous coronary intervention $(\mathrm{PCI})$. The patients were divided into two groups according to their SS-II (SS-II $\leq 32$ as low group [ $n=241$ ] and SS-II $>32$ as moderate-high group [ $n=61]$ ). Results: In-patients with moderate-high SS-II score were older. Level of N-terminal pro-B-type natriuretic peptide (NT-proBNP), troponin, wall motion score index and TIMl frame count were significantly higher in the moderate-high SS-II group than in the low SS-II group ( $p<0.05$, for all). Patients with moderate-high SS-II had low ejection fraction $(p<0.001)$. The composite outcome that consists of in-hospital all-cause mortality and major cardiovascular adverse events was significantly higher in the moderate-high SS-II group $(p=0.01)$. Selvester QRS score was significantly higher in moderate-high SS-II group than in the low SS-II group $(p<0.001)$. QRS score, hypertension, smoking and TIMI frame count were found to be independent predictors of the moderate-high SS-II. The cut-off value of QRS score for predicting SS-II on the basis of receiver operating characteristic (ROC) curve analysis was 9.0, with $50.9 \%$ sensitivity and $84.1 \%$ specificity (AUC: $0.726,95 \% \mathrm{Cl}: 0.648-0.804, p<0.001$ ).

Conclusion: QRS score is associated with SS-II predicting the severity of coronary artery disease and mortality in patients with STEMI undergoing primary $\mathrm{PCl}$. 


\section{Introduction}

Previous studies have documented the capability of different electrocardiographic (ECG) markers for prognostic assessment after ST-segment elevation myocardial infarction (STEMI). ${ }^{1}$ Patients with definite evidence of infarction on ECG have a worse prognosis compared with that of patients with possible infarction, and patients without QRS changes after infarction have the best prognosis. The standard 12-lead ECG can be used to estimate myocardial infarct size by calculating the Selvester QRS scoring system. ${ }^{2}$ A simplified Selvester QRS scoring system has been formed including only 37 criteria. ${ }^{3}$ QRS scores have also been shown to correlate with left ventricular (LV) function after initial myocardial infarction. ${ }^{4}$ Consequently, one would expect QRS scores also to be related to prognosis in patients with coronary artery disease (CAD).

The SYNTAX score (SS) is an angiographic lesion-based scoring system originally invented to evaluate the complexity of CAD. ${ }^{5}$ SS-II includes clinical variables determined by applying a Cox proportional hazards model to the results of the SYNTAX trial. ${ }^{6}$ In a study, investigating the predictive value of the SS-II compared to the SS-I, SS-II was found to have a better prognostic accuracy for patients with CAD. ${ }^{7}$ Furthermore, the SS-I and SS-II have been studied in patients with STEMI and both were found to be associated with long-term mortality and major adverse cardiac events. ${ }^{8,9}$ In addition, previous studies have shown that relationship between SS and myocardial infarct size determined with peak troponin in acute coronary syndrome. ${ }^{10,11}$

The present investigation aimed to evaluate the association of the SS-II with the Selvester QRS scoring system, which predicts the size of myocardial infarction in patients with STEMI.

\section{Methods}

\section{Study population}

At a single center where all procedures were performed (Ministry of Health, Adana City Training and Research Hospital), 302 consecutive patients $(71.8 \%$ males, mean age $55.1 \pm 12.2$ years) with STEMI who underwent primary percutaneous coronary intervention $(\mathrm{PCl})$ between December 2018 and March 2019 were retrospectively enrolled in the study. Subjects with a history of coronary artery bypass graft surgery, malignancy, severe liver or renal disease, inflammatory disease, each abnormality of ECG (bundle branch block, pre-excitation, ventricular hypertrophy, fascicular block) were excluded from the study. The patients were divided into two groups according to their SS-II. Patients with SSII $\leq 32$ were included in the low SS-II group ( $n=241,77.5 \%$ males) and patients with SS-II $>32$ were included in the moderate-high SS-II group ( $n=61,49 \%$ males).

STEMI was defined as follows: presentation with symptoms of ischemia that increased or occurred at rest within 12 to 24 hours of symptom onset; typical rise or fall in cardiac biomarker levels; ST-segment elevation $\geq 2.5 \mathrm{~mm}$ in men $<40$ years, $\geq 2 \mathrm{~mm}$ in men $\geq 40$ years, or $>1.5 \mathrm{~mm}$ in women in leads $V_{2}-V_{3}$ ST-segment elevation and/or $\geq 1 \mathrm{~mm}$ in the other leads (in the absence of LV hypertrophy or left bundle branch block) in $\geq 2$ contiguous leads observed on ECG. ${ }^{12}$

Baseline characteristics of patients with STEMI were recorded, such as age, gender, smoking status on admission, hypertension (HT), and diabetes mellitus (DM). The study was conducted according to the recommendations set forth by the Declaration of Helsinki on Biomedical Research Involving Human Subjects. The need for written informed consent waived due to the retrospective nature of the study.

\section{Laboratory parameters}

In all patients, antecubital venous blood samples into tubes were taken on admission before the patients started using any medications and they were transferred to the catheter laboratory. Blood counts were measured by a Sysmex K-1000 (Block Scientific, Bohemia, New York) autoanalyzer within 5 minutes of sampling. Plasma triglyceride, low-density lipoprotein (LDL), high-density lipoprotein (HDL), glucose, uric acid, and creatinine concentrations were measured with an automated chemistry analyzer (Abbott Aeroset, Minnesota) using commercial kits (Abbott). Activity of creatine kinase MB (CK-MB) was measured with an assay that uses 2 monoclonal antibodies (CK-MB STAT) on an Elecsys 2010 analyzer (Roche Diagnostics, Basel, Switzerland) by electrochemiluminescence immunoassay. Troponin $T$ was measured using a fourth-generation assay on an Elecsys 2010/cobas e 411 instrument (Roche Diagnostics).

\section{Coronary angiography and calculation of SYNTAX score II}

Coronary angiography was performed using the Judkins technique at 30 frames/second in multiple angulated views. Coronary angiograms were interpreted by an independent cardiologist who was unaware of the study data. Aspirin (300 mg), clopidogrel (loading dose of 600 $\mathrm{mg}$ and a maintenance dose of $75 \mathrm{mg}$ ), and unfractionated heparin (70-100 IU/kg bolus) were administered during the procedure. The SS-II for PCI was derived from the basic clinical features of the patients, as described previously. ${ }^{6}$ Briefly, the SS-II was calculated and points were added to the score according to a predefined algorithm, taking 6 other clinical variables (age, sex, left ventricular ejection fraction [LVEF], creatinine clearance $[\mathrm{CrCl}]$, chronic obstructive pulmonary disease [COPD], and peripheral artery disease [PAD]) into account. The Cockcroft and Gault formula was used to calculate $\mathrm{CrCl} .{ }^{13}$ COPD was defined as the long-term use of bronchodilators or steroids due to lung disease. PAD was identified by using Doppler ultrasound, palpation peripheral pulse or history of intermittent claudication. The patients were divided into two groups in accordance with the literature as follows; the low SS-II group and the moderate-high SS-II group.

Electrocardiographic and echocardiographic analysis Astandard 12-lead surface ECG (voltage: $10 \mathrm{~mm} / \mathrm{mV}$; speed: $25 \mathrm{~mm} / \mathrm{s}$ ) was performed before angiographic procedure. Each ECG was evaluated according to the simplified Selvester QRS scoring system. ${ }^{3}$ An individual QRS score was determined by consideration of 37 criteria based on R/Q 
or $\mathrm{R} / \mathrm{S}$ wave amplitude ratio or $\mathrm{Q}$ and $\mathrm{R}$ wave duration, or both. The QRS score ranged from 0 to 9 . According to the predefined thresholds, score 1 to 3 was lower, score $>9$ was the highest group. ${ }^{3}$

Left ventricular ejection fraction was determined using the Simpson method, according to the suggestions of the American Society of Echocardiography. ${ }^{14}$ A 16-segment model was used to semiquantitatively score regional wall motion abnormality. Wall motion was scored as $1=$ normal, 2 = hypokinesia, $3=$ akinesia, and $4=$ dyskinesia, and a wall motion score index (WMSI) was calculated for each segment using the sum of the score for all segments divided by the total number of segments.

\section{Outcomes and definitions}

In-hospital adverse events of all participants were recorded. Composite outcome consisted of all-cause mortality and major adverse cardiovascular events, including target-vessel revascularization, reinfarction, procedurerelated stroke, or transient ischemic attack, and need for intra-aortic balloon pump (IABP). Reinfarction was defined as clinically acute myocardial infarction that occurs during in-hospital follow-up. Similarly, target-vessel revascularization was defined as a recurrent $\mathrm{PCl}$ at the treated lesion within the in-hospital period.

\section{Statistical analysis}

Statistical analysis was carried out using SPSS Statistics for Windows, v. 20.0 (SPSS Inc., Chicago, Illinois, USA) and MedCalc statistical software v19.5.6 (Ostend, Belgium). Continuos variables are expressed as mean \pm SD or median (interquartile range, IQR), whereas categorical variables are expressed as percentage (\%) and number (n). Continuous variables were tested for normality distribution using an analytical (KolmogorovSmirnov test) method and visual methods (histograms and probability plots). The independent-sample t-test or the Mann-Whitney $U$ test were used to analyze continuous variables as appropriate. Categorical variables were compared using the $\chi^{2}$ test or the Fisher's exact test. Spearman correlation analysis was used to investigate the association between SS-II and possible parameters. Multivariate forward stepwise logistic regression analysis was used to identify independent predictors of moderate-to-high SS-II and in-hospital composite outcome of all-cause mortality and major cardiovascular events. All significant parameters with a $p$-value of $\leq 0.1$ in the univariate analysis were selected for the multivariate model. The optimal QRS score cut-off point for predicting SS-II was calculated using receiver operating characteristic (ROC) analysis. The area under the curve (AUC) value was calculated as a measure of the accuracy of the test. AUC comparison of these predictors was performed using the DeLong method. Youden index method was used to determine predictive values of independent predictors. A two-tailed $p$-value of less than 0.05 was considered statistically significant.

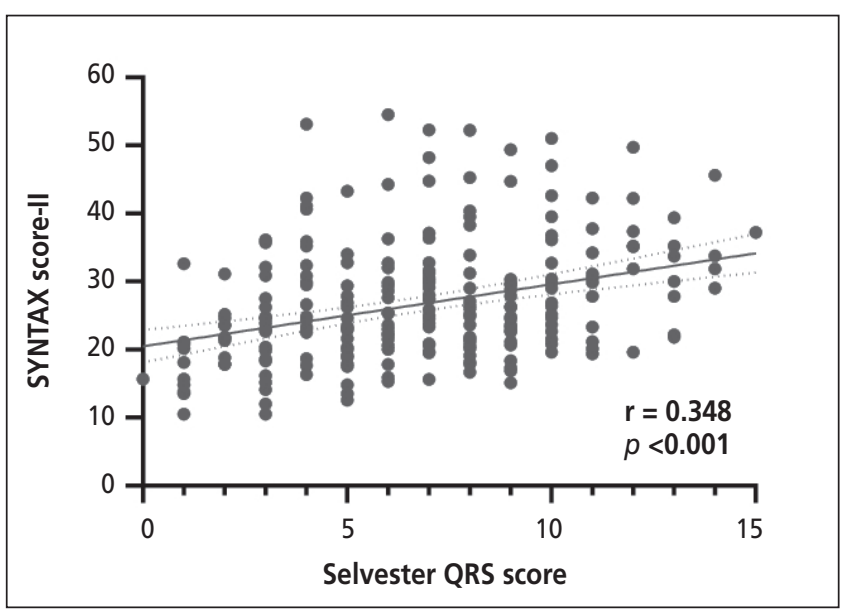

Fig. 1 - Scatter plot diagram depicting the association of SS-II with Selvester QRS score.

\section{Results}

QRS scores, the baseline clinical, laboratory, echocardiographic and angiographic characteristics of the study population are listed in Table 1. The patients with moderate-high SS-II were older and female. Smoking was significantly higher in the low SS-II group than in the moderate-high SS-II group $(p<0.001)$ whereas HT was higher in the the moderate-high SS-II group $(p<0.001)$. There is no difference between the two groups in terms of STEMI subgroups $(p=0.743)$. Level of $\mathrm{N}$-terminal pro-B-type natriuretic peptide (NT-proBNP), troponin and CK-MB on admission, WMSI, and TIMI frame count were significantly higher in the moderate-high SS-II group than in the other group ( $p<0.05$, for all). Patients with moderate-high SS-II had lower LVEF $(p<0.001)$. Selvester QRS score was significantly higher in moderate-high SSII group than in the low SS-II group $(p<0.01)$. All-cause mortality, target-vessel revascularization, procedure-related stroke, re-infarction, and the composite outcome of all-cause mortality and major adverse cardiovascular events were significantly higher in those with moderate-high SS-II than in those with low SS-II (Table 2). NT-proBNP $(r=0.425, p<0.001)$, peak troponin $(r=0.349, p<0.001)$, TIMI frame count $(r=0.252$, $p<0.001)$, and Selvester QRS score $(r=0.348, p<0.001)$ (Fig. 1) were positively correlated with SS-II (Table S1).

Predictors of moderate-high SS-II and composite outcome of all-cause mortality and major cardiovascular events are shown in Table 3B. In forward stepwise logistic regression analysis, $\mathrm{HT}$ [odds ratio $(\mathrm{OR})=3.572,95 \%$ confidence interval $(\mathrm{Cl}): 1,550-8.229, p=0.003]$, TIMI frame count $(\mathrm{OR}=1.038,95 \% \mathrm{Cl} 1.015-1.060, p=0.001$, and QRS score (OR $=1.299,95 \% \mathrm{Cl} 1.123-1.502, p<0.001$ ) were observed to be independent predictors of moderate-high SS-II whereas smoking was negatively corelated with moderate-to-high SS-II (OR $=0.152,95 \% \mathrm{Cl}: 0.064-0.364$, $p<0.001$ ] (Table 3A). In the prediction of in-hospital composite outcome of all-cause mortality and major cardiovascular events; Ejection fraction had a protective effect (OR $=0.813,95 \% \mathrm{Cl}: 0.730-0.906, p<0.001)$, whereas Killip class III-IV was found to be independent predictor of 
Table 1 - Comparison of baseline, laboratory, echocardiographic and angiographic characteristics of groups

\begin{tabular}{|c|c|c|c|c|}
\hline Variables & All (n: 302) & Low SS-II group (n: 241) & $\begin{array}{l}\text { Moderate-high SS-II } \\
\text { group (n: } 61)\end{array}$ & $p$-value \\
\hline \multicolumn{5}{|l|}{ Baseline characteristics } \\
\hline Age, years & $55.1 \pm 12.2$ & $51.9 \pm 10.4$ & $67.6 \pm 10.8$ & $<0.001$ \\
\hline Gender (male), n (\%) & $216(71.5)$ & $186(77.2)$ & $30(49.2)$ & $<0.001$ \\
\hline $\mathrm{BMI}, \mathrm{kg} / \mathrm{m}^{2}$ & $26.9(24.6-29.4)$ & $27.0(24.7-29.4)$ & $26.4(23.9-30.3)$ & 0.555 \\
\hline Smoking, n (\%) & $209(69.2)$ & $189(78.4)$ & $20(33.3)$ & $<0.001$ \\
\hline $\begin{array}{l}\text { Systolic blood pressure, on admission, } \\
\mathrm{mmHg}\end{array}$ & $127(112-142)$ & $130(113-145)$ & $120(109-141)$ & 0.078 \\
\hline Diabetes, n (\%) & $63(20.9)$ & $47(19.5)$ & $16(26.2)$ & 0.220 \\
\hline Hypertension, n (\%) & $109(36.1)$ & $71(29.5)$ & $38(62.3)$ & $<0.001$ \\
\hline CAD, n (\%) & $15(4.9)$ & $13(5.4)$ & $2(3.3)$ & 1.000 \\
\hline $\mathrm{HL}, \mathrm{n}(\%)$ & $47(15.6)$ & $38(15.8)$ & $9(14.8)$ & 1.000 \\
\hline COPD, n (\%) & $35(11.6)$ & $23(9.5)$ & $12(19.7)$ & 0.052 \\
\hline PAD, n (\%) & $14(4.6)$ & $9(3.7)$ & $5(8.1)$ & 0.265 \\
\hline History of family, n (\%) & $133(44.0)$ & $114(47.3)$ & $19(31.1)$ & 0.038 \\
\hline \multicolumn{4}{|l|}{ Killip classification } & 0.053 \\
\hline Class I-II & $292(96.7)$ & $236(97.9)$ & $56(91.8)$ & \\
\hline Class III-IV & $10(3.3)$ & $5(2.1)$ & $5(8.1)$ & \\
\hline \multicolumn{5}{|l|}{ Laboratory findings } \\
\hline Glucose, mg/dL & 139 (118-196) & $133(115-176)$ & $175(130-235)$ & 0.001 \\
\hline Creatinine, mg/dL & $0.8(0.7-1.0)$ & $0.8(0.7-1.0)$ & $0.8(0.7-1.0)$ & 0.800 \\
\hline Uric acid, mg/dL & $5.3(4.3-6.4)$ & $5.3(4.4-6.4)$ & $5.3(3.9-6.7)$ & 0.871 \\
\hline NT-proBNP, pg/mL & $163.0(68.9-850.5)$ & $122.5(59.3-554.8)$ & $873.0(188.5-2345.0)$ & $<0.001$ \\
\hline CK-MB, on admission ( $\mathrm{ng} / \mathrm{mL}$ ) & $9.0(2.5-48.9)$ & $7.2(2.3-47.6)$ & $15.3(4.1-93.7)$ & 0.036 \\
\hline CK-MB, peak (ng/mL) & $159.4(54.9-300.0)$ & $150.6(51.9-291.3)$ & $213.0(78.4-300.0)$ & 0.110 \\
\hline Troponin $\mathrm{T}$, on admission (pg/mL) & $134.2(25.8-834.5)$ & $103.2(22.9-707.0)$ & $304.4(52.1-1894.0)$ & 0.010 \\
\hline Troponin T, peak (pg/mL) & $4678.0(1669.0-8948.0)$ & $4284.0(1376.3-8516.5)$ & $6515.0(3821.0-10000.0)$ & 0.002 \\
\hline Triglycerides, mg/dL & $121(72-192)$ & $132(74-217)$ & $95(59-151)$ & 0.016 \\
\hline Total cholesterol, mg/dL & $197(177-226)$ & $198(179-222)$ & $190(160-235)$ & 0.162 \\
\hline $\mathrm{HDL}, \mathrm{mg} / \mathrm{dL}$ & $39(32-47)$ & $38(32-46)$ & $43(34-49)$ & 0.013 \\
\hline $\mathrm{LDL}, \mathrm{mg} / \mathrm{dL}$ & $130(112-151)$ & $130(113-148)$ & $126(97-158)$ & 0.163 \\
\hline \multicolumn{4}{|l|}{ STEMI subgroups, $\mathrm{n}(\%)$} & 0.743 \\
\hline Anterior & $124(41.1)$ & $94(39.0)$ & $30(49.2)$ & \\
\hline Inferior or inferoposterior & $125(41.4)$ & $104(43.2)$ & $21(34.4)$ & \\
\hline Posterior & $26(8.6)$ & $21(8.7)$ & $5(8.2)$ & \\
\hline Lateral & $16(5.3)$ & $13(5.4)$ & $3(4.9)$ & \\
\hline Right ventricle & $11(3.6)$ & $8(3.3)$ & $2(3.3)$ & \\
\hline \multicolumn{5}{|l|}{ Echocardiographic findings } \\
\hline $\operatorname{LVEF}(\%)$ & $43.8 \pm 7.0$ & $45.4 \pm 6.3$ & $37.2 \pm 5.7$ & $<0.001$ \\
\hline LVESV, mm & $64.1 \pm 18.2$ & $60.9 \pm 16.1$ & $76.4 \pm 20.7$ & $<0.001$ \\
\hline LVEDV, mm & $114.0 \pm 22.0$ & $112.5 \pm 21.1$ & $120.2 \pm 24.6$ & 0.025 \\
\hline WMSI & $1.31(1.19-1.44)$ & $1.25(1.19-1.38)$ & $1.5(1.38-1.75)$ & $<0.001$ \\
\hline \multicolumn{5}{|c|}{ Electrocardiographic and angiographic characteristics } \\
\hline TIMI frame count & $34(26-44)$ & $33(24-41)$ & $44(33-60)$ & $<0.001$ \\
\hline Selvester QRS score & $7(4-9)$ & $6(4-9)$ & $8(6-11)$ & $<0.001$ \\
\hline Door-to-balloon time, min & $59.6 \pm 13.5$ & $59.0 \pm 13.6$ & $62.0 \pm 12.9$ & 0.161 \\
\hline
\end{tabular}

Data are presented as number (\%), mean \pm standard deviation or median (minimum-maximum). $P$-value was calculated using the Independent Samples t-test or the Mann-Whitney U-test for continuous variables and the Chi-square test or the Fisher's exact test for categorical variables as appropriate. $P$-value $<0.05$ was considered significant.

$\mathrm{BMI}$ - body mass index; CAD - coronary artery disease; CK-MB - creatine kinase myocardial band; HDL - high-density lipoprotein; HL - hyperlipidemia; LDL - low-density lipoprotein; LVEDV - left ventricular end-diastolic volume; LVEF - left ventricular ejection fraction; LVESV - left ventricular end-systolic volume; NT-proBNP - N-terminal pro-B-type natriuretic peptide; WMSI - wall motion score index. 


\begin{tabular}{l|l|l|l|}
\hline \multicolumn{3}{|l}{$\begin{array}{l}\text { Table S1 - Association of SYNTAX score-ll with certain biochemi- } \\
\text { cal parameters, TIMI frame count, and Selvester QRS score }\end{array}$} \\
\hline & \multicolumn{1}{|l}{$\boldsymbol{r}^{*}$} & $\boldsymbol{p}$ \\
\hline NT-proBNP, pg/mL & 0.425 & $<0.001$ \\
\hline Troponin, peak, pg/ml & 0.349 & $<0.001$ \\
\hline Systolic blood pressure, mmHg & -0.193 & $\mathbf{0 . 0 0 2}$ \\
\hline TIMI frame count & 0.252 & $<0.001$ \\
\hline Glucose, mg/dL & 0.199 & $\mathbf{0 . 0 0 1}$ \\
\hline Triglycerides, mg/dL & -0.220 & $<0.001$ \\
\hline Selvester QRS score & 0.348 & $<0.001$ \\
\hline HDL, mg/dL & 0.256 & $<0.001$ \\
\hline
\end{tabular}

* Spearman correlation. HDL - high-density lipoprotein; NT-proBNP - N-terminal pro-B-type natriuretic peptide.

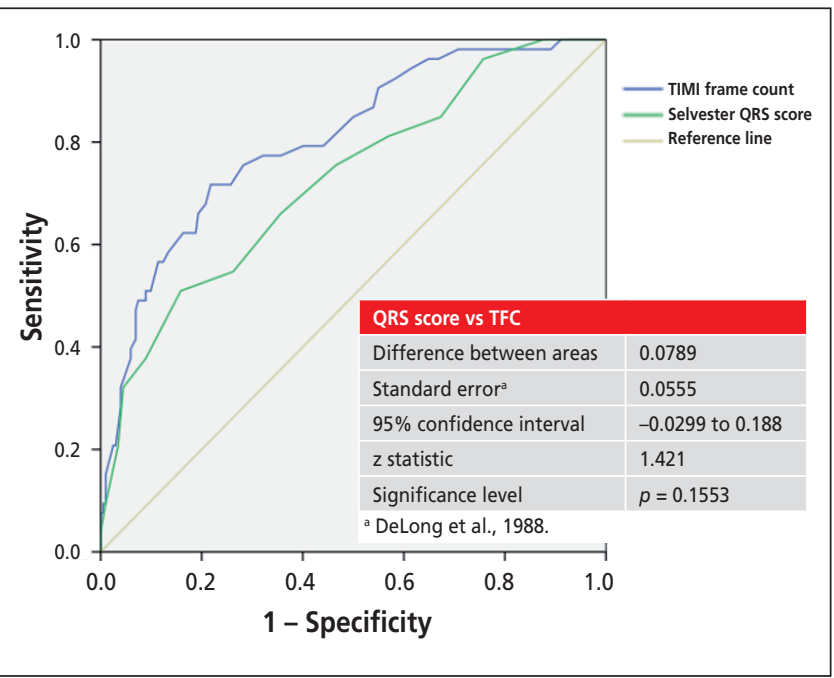

Fig. 2 - QRS score to predict SS-II based on ROC curve analysis.

composite adverse outcomes (OR $=9.509,95 \% \mathrm{Cl}: 1.400$ 64.597, $p=0.021$ ] (Table 3B).

The cut-off value of Selvester QRS score for predicting moderate-high SS-II on the basis of ROC curve analysis was 9.0, with $50.94 \%$ sensitivity and $84.16 \%$ specificity (AUC: $0.726,95 \% \mathrm{Cl}: 0.648-0.804, p<0.001]$. The cut-off value of TIMI frame count for predicting moderate-high SS-II was 39, with $71.70 \%$ sensitivity and $78.22 \%$ specificity (AUC: 0.805, 95\% Cl: 0.738-0.872), $p<0.001$ ] (Fig. 2). There was no statistical significance in the pairwise comparison of the predictors $(p=0.155)$.

\section{Discussion}

To the best of our knowledge, this is the first study to investigate the relationship between QRS score and SS-II, which shows the severity of CAD and mortality. The main finding of the present study is that HT, TIMI frame count, and QRS score were independently associated with moderate-high SS-II, while smoking had a negative correlation with moderate-high SS-II.

The importance of SS-I in predicting worse outcomes and mortality has been demonstrated by many previous studies. The reason we chose SS-II in our study is that it is superior to SS-I in demonstrating both in-hospital and long-term mortality. ${ }^{15}$ Wang et al. reported SS-II has also proven to be superior in predicting major adverse cardiac events for STEMI patients treated with primary $\mathrm{PCl}{ }^{9}$

The presence of $Q$ waves on the presentation ECG reflects a further stage in the evolution of the infarct. This ECG marker is superior to time from symptom onset in predicting mortality in STEMI patients treated with primary PCI. QRS score is a quantitative index of myocardial damage calculated not only using the number of $Q$ waves but also increased $Q$ wave width and decreased $\mathrm{R}$ wave amplitude and width. Selvester QRS score is directly related to the extent of myocardial damage, and the relationship between reduced LVEF associated with the infarct size in STEMI patients and development of heart failure is well-known. ${ }^{16}$ Hiroki Shiomi et al. found infarct size in STEMI patients undergoing primary $\mathrm{PCl}$, a high total number of ST-segment elevated derivation on ECG, low LVEF, partial ST-segment resolution, increased frequency of anterior wall infarction, and high CK-MB levels were associated with a high QRS score. In the same study, major adverse cardiovascular events such as all-cause death, cardiac death, sudden cardiac death, and congestive heart failure were more common in the group with a higher QRS score. ${ }^{17}$ Uyarel et al. reported, in STEMI patients undergoing primary $\mathrm{PCl}$, major adverse cardiac events on day 30 were more frequent than in the patient group with a high QRS score. ${ }^{18}$ Tjandrawidjaja et al. found the risk of death was 2-fold increased in STEMI patients with a QRS score of $\geq 4$ on day 90 undergoing primary $\mathrm{PCl}^{19}$ Similarly, in our unadjusted analysis, Selvester QRS score was found to be associated with the composite outcome that consists of in-hospital all-cause mortality and major cardiovascular adverse events (Table 3B).

The increase in troponin levels always anticipates myocyte damage and necrosis. ${ }^{20}$ According to the study

\begin{tabular}{|l|l|l|l|l|l|}
\hline \multicolumn{3}{|l}{ Table 2 - Comparison of in-hospital all-cause mortality and major adverse cardiovascular events between the groups } \\
\hline Variables & All (n: 302) & Low SS-II group (n: 241) & Moderate-high SS-II group (n: 61) & p-value \\
\hline All-cause mortality & $11(3.6)$ & $5(2.1)$ & $6(9.8)$ & $\mathbf{0 . 0 1 8}$ \\
\hline Target vessel revascularization & $10(3.3)$ & $5(2.1)$ & $5(8.2)$ & 0.05 \\
\hline Stroke & $2(0.7)$ & $0(0)$ & $2(3.3)$ & NA \\
\hline Re-infarct & $9(2.9)$ & $4(1.7)$ & $5(8.2)$ & 0.031 \\
\hline Need for IABP & $2(0.7)$ & $2(0.8)$ & $0(0)$ & NA \\
\hline Composite outcome & $18(5.9)$ & $8(3.3)$ & $10(16.4)$ & 0.001 \\
\hline
\end{tabular}

IABP - intra-aortic balloon pump; NA - non-available. 
Table 3A - Independent predictors of moderate-high SYNTAX score II

\begin{tabular}{|l|l|l|l|l|}
\hline Variable & Univariate analysis & \multicolumn{2}{l}{ Multivariate analysis } \\
\hline NT-proBNP, per $10 \mathrm{pg} / \mathrm{mL}$ increase & OR $(95 \% \mathrm{Cl})$ & $p$-value & OR $(95 \% \mathrm{Cl})$ & - \\
\hline Hypertension & $1.006(1.004-1.009)$ & $<0.001$ & - & 0.003 \\
\hline Diabetes mellitus & $4.042(2.126-7.686)$ & $<0.001$ & $3.572(1.550-8.229)$ \\
\hline Troponin peak, per $100 \mathrm{pg} / \mathrm{mL}$ increase & $1.551(0.766-3.141)$ & 0.222 & - & - \\
\hline Systolic blood pressure, $\mathrm{mmHg}$ & $1.014(1.005-1.023)$ & $\mathbf{0 . 0 0 2}$ & - & - \\
\hline History of family & $0.988(0.976-1.001)$ & 0.063 & - & - \\
\hline TIMI frame count & $0.504(0.263-0.968)$ & 0.040 & - & - \\
\hline Current smoker & $1.044(1.025-1.065)$ & $<0.001$ & $1.038(1.015-1.060)$ & 0.001 \\
\hline Glucose, mg/dL & $0.138(0.070-0.269)$ & $<0.001$ & $0.152(0.064-0.364)$ & $<0.001$ \\
\hline Triglycerides, mg/dL & $1.006(1.002-1.010)$ & $\mathbf{0 . 0 0 2}$ & - & - \\
\hline HDL, mg/dL & $0.998(0.995-1.001)$ & 0.210 & - & - \\
\hline Selvester QRS score & $1.035(1.007-1.064)$ & 0.013 & - & - \\
\hline Killip class III-IV & $1.244(1.118-1.383)$ & $<0.001$ & - & $<0.001$ \\
\hline
\end{tabular}

$P$-value $<0.05$ was considered significant. HDL - high-density lipoprotein; NT-proBNP - N-terminal pro-B-type natriuretic peptide. Nagelkerke $^{2}$ : 0.475, $p<0.001$; model chi-square: 85.001; -2 Log likelihood: 150.809.

Table 3B - Independent predictors of composite outcome of in-hospital all-cause mortality and major adverse cardiovascular events

\begin{tabular}{|l|l|l|l|l|}
\hline Variable & Univariate analysis & \multicolumn{2}{l}{ Multivariate analysis } \\
\hline Age, years & OR $(95 \% \mathrm{Cl})$ & $p$-value & OR $(95 \% \mathrm{Cl})$ & - \\
\hline Gender, male, $\mathrm{n}(\%)$ & $1.022(0.980-1.066)$ & 0.309 & - & - \\
\hline Systolic blood pressure, $\mathrm{mmHg}$ & $0.920(0.283-2.988)$ & 0.889 & - & - \\
\hline Ejection fraction, \% & $0.963(0.939-0.988)$ & $\mathbf{0 . 0 0 4}$ & - & - \\
\hline Peak troponin, per $100 \mathrm{pg} / \mathrm{mL}$ increase & $0.838(0.769-0.912)$ & $<0.001$ & $0.813(0.730-0.906)$ & $<0.001$ \\
\hline Selvester QRS score & $1.012(0.996-1.027)$ & 0.136 & - & - \\
\hline Killip class III-IV & $1.253(1.054-1.489)$ & $\mathbf{0 . 0 1 1}$ & - & - \\
\hline
\end{tabular}

Nagelkerke $R^{2}: 0.307, p<0.001$; model chi-square: $28.153,-2$ Log likelihood: 78.937.

of Yamazaki et al., troponin levels in patients with CAD were shown to be associated with the severity and diffuseness of CAD. ${ }^{21}$ The study by Christian Eke et al. reported the relationship between WMSI and infarct size in patients with NSTEMI. ${ }^{22}$ In another study conducted in both STEMI and NSTEMI patients revealed the association of WMSI with cardiovascular events. ${ }^{23}$ In our study, compatible with these studies, troponin levels, WMSI, and Selvester QRS score associated with infarct size were found to be significantly higher in the group with moderate-high SS-II, which predicts major adverse cardiovascular events.

The presence of HT has been proven to be one of the main risk factors for CAD in many previous studies. In our study, HT was found to be an independent predictor of the moderate-high SS-II. Çağdaş et al. showed the frequency of HT was detected to be similar between two groups divided according to the SS-I, which is an anatomical classification, whereas, similar to our study, HT was more frequent in patients with high SS-II in the presence of a grouping according to SS-II and HT was an independent marker for the high SS-II. ${ }^{24}$ We may attribute this similarity to the SS-II being not only an anatomical but also a clinical classification.

Some studies have found a lower mortality rate in the smoking group amongst STEMI patients. ${ }^{25-27}$ This finding, called Smoker's paradox, was attributed to a poorer risk profile in non-smokers. In the study by Albertal et al., the smoker group was significantly younger and chronic diseases such as DM were less and also, TIMI frame count and myocardial blush grade after the procedure, which are related to coronary flow, were higher in the smoker group. ${ }^{28}$ In our study, smoking was found to be significantly higher in low SS-II. We thought that this result might be related to the younger and lower risk profile of the smoker group than the non-smokers (mean age $51.7 \pm 10.2$ vs $62.8 \pm 13.0$ years, $p<0.001$ ). The fact that SS-II is a clinical classification and an increase in the frequency of these clinical parameters with age may also help us to explain this paradox. 


\section{Study limitations}

The study has the following limitations: Study had a single-center design including patients with only STEMI who underwent emergency PCI. Selvester QRS score was only calculated on admission or before coronary angiography. Although Selvester QRS score was independently associated with SS-2, it had a poor relationship to in-hospital events. This could possibly be related to the design, sample size, and thereby the insufficient number of composite outcomes to reveal their association with the Selvester QRS score with a strong statistical analysis. In addition, we could not analyze the long-term follow-up of the patients after discharge. Consequently, prospective and well-attended studies are required to further comprehend the association of QRS score with the severity of CAD in patients with non-STEMI and stable CAD.

\section{Conclusion}

In STEMI patients, we showed that the Selvester QRS score, which is easy to calculate, cheap, and non-invasive method, is associated with the moderate-high SS-II. 12-lead ECG, sufficient to calculate the Selvester QRS score, could give us information about patient's prognosis. Patients with a high QRS score may need to be followed up closely in terms of complications before and after the procedure. Attention should be, therefore, paid to major adverse cardiac events in long-term follow-up.

\section{Conflict of interest}

No conflict of interest was declared by the authors.

\section{Funding}

There is no funding source to declare.

\section{Ethical statement}

Çukurova University Ethic Board Committee approved the study, and all the participants provided their written informed consent. Decision number: 105, date: 06.11.2020.

\section{References}

1. Reindl M, Reinstadler SJ, Feistritzer HJ, et al. Persistent T-wave inversion predicts myocardial damage after STelevation myocardial infarction. Int J Cardiol 2017;241:7682.

2. Selvester RH, Wagner GS, Hindman NB. The Selvester QRS scoring system for estimating myocardial infarct size. The development and application of the system. Arch Intern Med 1985;145:1877-1881.

3. Bounous EP Jr, Califf RM, Harrell FE Jr, et al. Prognostic value of the simplified Selvester QRS score in patients with coronary artery disease. J Am Coll Cardiol 1988;11:35-41.

4. Palmeri ST, Harrison DG, Cobb FR, et al. QRS Scoring System for Assessing Left Ventricular Function After Myocardial Infarction. N Engl J Med 1982;306:4-9.

5. Sianos G, Morel MA, Kappetein AP, et al. The SYNTAX Score: an angiographic tool grading the complexity of coronary artery disease. Eurolntervention 2005;1:219-227.
6. Farooq V, van Klaveren D, Steyerberg EW, et al. Anatomical and clinical characteristics to guide decision making between coronary artery bypass surgery and percutaneous coronary intervention for individual patients: development and validation of SYNTAX score II. Lancet 2013;381:639-650.

7. Campos CM, van Klaveren D, lqbal J, et al. Predictive performance of SYNTAX score II in patients with left main and multivessel coronary artery disease. Circ J 2014;78:1942-1949.

8. Magro M, Nauta S, Simsek C, et al. Value of the SYNTAX score in patients treated by primary percutaneous coronary intervention for acute STelevation myocardial infarction: The MI SYNTAX score study. Am Heart J 2011;161:771-781.

9. Wang G, Wang $C$, Zhang $Y$, et al. Usefulness of the SYNTAX score II to predict 1-year outcome in patients with primary percutaneous coronary intervention. Coron Artery Dis 2016;27:483-489.

10. Tricoci P, Leonardi S, White J, et al. Cardiac troponin after percutaneous coronary intervention and 1-year mortality in non-ST-segment elevation acute coronary syndrome using systematic evaluation of biomarker trends. J Am Coll Cardiol 2013;62:242-251.

11. Palmerini $T$, Genereux $P$, Caixeta $A$, et al. Prognostic value of the SYNTAX score in patients with acute coronary syndromes undergoing percutaneous coronary intervention: analysis from the ACUITY (Acute Catheterization and Urgent Intervention Triage StrategY) trial. J Am Coll Cardiol 2011;57:23892397.

12. Thygesen K, Alpert JS, Jaffe AS, et al. Fourth universal definition of myocardial infarction (2018). Eur Heart J 2018;72:2231-2264.

13. Cockcroft DW, Gault H. Prediction of creatinine clearance from serum creatinine. Nephron 1976;16:3141.

14. Schiller NB, Shah PM, Crawford M, et al. Recommendations for quantitation of the left ventricle by two-dimensional echocardiography. American Society of Echocardiography Committee on Standards, Subcommittee on Quantitation of Two-Dimensional Echocardiograms. J Am Soc Echocardiogr 1989;2:358367.

15. Karabağ $Y$, Çağdaş $M$, Rencuzogullari I, et al. Comparison of SYNTAX score II efficacy with SYNTAX score and TIMI risk score for predicting in-hospital and long-term mortality in patients with ST segment elevation myocardial infarction. Int J Cardiovasc Imaging 2018;34:1165-1175.

16. Ideker RE, Wagner GS, Ruth WK, et al. Selvester RH. Evaluation of a QRS scoring system for estimating myocardial infarct size. II. Correlation with quantitative anatomic findings for anterior infarcts. Am J Cardiol 1982;49:1604-1614.

17. Shiomi H, Kosuge M, Morimoto T, et al. CREDOKyoto AMI Investigators. QRS score at presentation electrocardiogram is correlated with infarct size and mortality in ST-segment elevation myocardial infarction patients undergoing primary percutaneous coronary intervention. Circ J 2017;81:1129-1136.

18. Uyarel H, Cam N, Okmen E, et al. Level of Selvester QRS score is predictive of ST-segment resolution and 30-day outcomes in patients with acute myocardial infarction undergoing primary coronary intervention. Am Heart J 2006;151:e1231-e1237.

19. Tjandrawidjaja MC, Fu Y, Westerhout CM, et al. Usefulness of the QRS score as a strong prognostic marker in patients discharged after undergoing primary percutaneous coronary intervention for STsegment elevation myocardial infarction. Am J Cardiol 2010;106:630-634.

20. Petrie CJ, Weir RA, Anwar MS, et al. High sensitivity troponin $\mathrm{T}$ in acute medicine; more questions than answers. QJM 2014;107:193-200. 
21. Yamazaki K, lijima R, Nakamura M, Sugi K. Highsensitivity cardiac troponin T level is associated with angiographic complexity of coronary artery disease: a cross-sectional study. Heart Vessels 2016;31:890-896.

22. Eek C, Grenne B, Brunvand $H$, et al. Strain echocardiography and wall motion score index predicts final infarct size in patients with non-ST-segmentelevation myocardial infarction. Circ Cardiovasc Imaging 2010;3:187-194.

23. Jurado-Roman A, Agudo-Quilez P, Rubio-Alonso B, et al. Superiority of wall motion score index over left ventricle ejection fraction in predicting cardiovascular events after an acute myocardial infarction. Eur Heart J Acute Cardiovasc Care 2019;8:78-85.

24. Çağdaş M, Rencüzoğullari I, Karakoyun S, et al. Assessment of relationship between C-reactive protein to albumin ratio and coronary artery disease severity in patients with acute coronary syndrome. Angiology 2019;70:361-368.
25. Zhang $C$, Jiang $L, X u L$, et al. Implications of $\mathrm{N}$-terminal pro-B-type natriuretic peptide in patients with three-vessel disease. Eur Heart J 2019;40:33973405.

26. Lee JH, Kim JH, Jang SY, et al. A new tool for the risk stratification of patients undergoing primary percutaneous coronary intervention with ST-segment elevation myocardial infarction: Bio-Clinical SYNTAX score. Int J Cardiol 2015;187:193-195.

27. Barbash GI, White HD, Modan M, Van der Werf F. Smoking and acute myocardial infarction. Circulation 1993;87:1427-1428.

28. Albertal M, Cura F, Escudero AG, et al. Mechanism involved in the paradoxical effects of active smoking following primary angioplasty: a subanalysis of the protection of distal embolization in high-risk patients with acute myocardial infarction trial. J Cardiovasc Med 2008;9:810-812. 